\title{
Los ancestros y su representatividad en Changó, el gran putas ${ }^{60}$ The ancestors and their representation in Changó, El gran putas.
}

\author{
Elizabeth Santafé Varcárcel
}

Recibido: 20 de Marzo 2011. Aprobado: 30 de Abril de 2011

\begin{abstract}
Resumen
El culto a los Ancestros es esencial en la actitud del negro ante la vida, por eso el autor los convierte en el eje filosófico y cultural con el cual crea la saga libertadora de la novela Changó, el Gran Putas. Manuel Zapata Olivella trasciende el universo mítico y filosófico Yoruba-Bantú, con los Dioses, Orichas y Ancestros, de los que se origina la memoria genésica del hombre africano, para reconstruir la diáspora de millones de prisioneros traídos a América, de pronto como diría Mircea Eliade, en un deseo de encontrar un sentido transhistórico a los acontecimientos históricos de un grupo humano señalado por la fatalidad; o de denunciar lo que la humanidad xenófoba y excluyente ha ocultado del colonialismo opresor durante siglos.
\end{abstract}

Palabras clave: Manuel Zapata Olivella; Changó, el gran putas; Novela afrocolombiana.

\begin{abstract}
The cult to the ancestors is essential in the black attitude towards life, so the author makes them the philosophical and cultural axis by which is created the liberation saga novel Chango, El gran putas. Manuel Zapata Olivella transcends the mythic and philosophical universe Yoruba-Bantu, with the Gods, Ancestors and Orichas, from which reproductive memory is originates African man to rebuild the diaspora of millions of prisoners brought to America, probably as Mircea say Eliade, in a desire to find a trans-historic sense to the events of a group appointed by the fatality, or to denounce what the xenophobic and exclusionary humanity has been hidden for centuries of oppressive colonialism.
\end{abstract}

Keywords: Manuel Zapata Olivella; Changó, el gran putas; Afrocolombian novel.

"Zapata Olivella es el "guardián de los Ancestros", protector de la memoria ancestral y legendaria africana, que los Orichas y las tablas de Ifá-fa eligieron para reproducir e inventar toda la sabiduría del hombre africano en su diáspora homérica, en busca de su libertad efectiva".

William Mina Aragón ${ }^{61}$

Manuel Zapata Olivella trasciende el universo mítico y filosófico Yoruba-Bantú, con los Dioses, Orichas y Ancestros, de los que se origina la memoria genésica del hombre

\footnotetext{
${ }^{60}$ Ensayo de resultado de la tesis de Maestría en Literaturas Colombiana y Latinoamericana -Los ancestros y su representatividad en Changó el gran putas- defendida en el 2011 en la Universidad del Valle. Es parte del grupo de investigación Narrativa Colombiana.

${ }^{61}$ Zapata Olivella, Manuel. El Árbol Brujo de la Libertad. Artes Gráficas del Valle.2000. Prólogo. p.22.
} 
africano, para reconstruir la diáspora de millones de prisioneros traídos a América, de pronto como diría Mircea Eliade ${ }^{62}$, en un deseo de encontrar un sentido transhistórico a los acontecimientos históricos de un grupo humano señalado por la fatalidad; o de denunciar lo que la humanidad xenófoba y excluyente ha ocultado del colonialismo opresor durante siglos.

De toda la cosmogonía africana, el culto a los Ancestros es esencial en la actitud del negro ante la vida, por eso el autor los convierte en el eje filosófico y cultural con el cual crea la saga libertadora de la novela Changó, el Gran Putas, en cuyo Cuaderno de Bitácora precisa: "Los Ancestros son venerados por convivir con los Orichas creadores del mundo. Muchos de ellos en virtud de las obras ejecutadas en la vida se les adoran como semidioses"

El tributo a los ascendientes difuntos, paternos o maternos, se constituye en el fundamento de la sabiduría africana transplantada al continente Americano, pues según las creencias, los mortales son alimentados en vida por dos Sombras protectoras inseparables que los acompañan espiritualmente desde que son engendrados hasta que mueren. Una Sombra es el origen de la vida, aquella que siembra el Kulonda, la semilla del magara en el útero materno portadora asimismo, de la inteligencia, la palabra y la creatividad. La otra, es la Sombra de la descendencia que se proyecta invisible en la sangre de las nuevas generaciones. Por lo tanto, los difuntos sobreviven para dar origen a la vida biológica. El negro nunca se encuentra solo, porque a su lado, al alcance de sus palabras, están sus Sombras dispuestas a protegerlo.

Para Zapata Olivella la tradición de rendir homenaje a los muertos, promueve el anhelo de liberación de los esclavos, ya que los Orichas y Ancestros son los verdaderos amos espirituales desde el principio de los tiempos, con quienes es fácil comunicarse usando la inteligencia, la palabra, el canto, los tambores y la danza, más que todo celebrados en los altares familiares, velorios o visitas a la tumba: "Desde luego, el ritual sagrado trascendió a la familia, la cultura y la lucha por la libertad"64.

\footnotetext{
${ }^{62}$ Mircea, Eliade. El Mito del eterno retorno. Arquetipos y repetición. Emecé Editores, Argentina, 2001. p. 92

${ }^{63}$ Zapata Olivella. Changó, el Gran Putas. Editorial Oveja Negra. Biblioteca de Literatura Colombiana, Bogotá, Colombia, 1983. p.512

${ }^{64}$ ZAPATA Olivella, Manuel. El Árbol Brujo de la Libertad. África en Colombia - orígenes - Transculturación Presencia- Ensayo Histórico Mítico y Antropológico. Artes Gráficas del Valle Ltda. 2002. P.111
} 
Estas nociones ontogénicas enriquecen el sentimiento religioso de los prisioneros africanos, donde quiera que desembarquen en América y, les permiten sobrevivir a la pérdida de la totalidad de sus derechos como seres humanos. Este arquetipo del modelo ancestral lo repiten en el Lumbalú del Palenque de San Basilio y en el Alabado o Gualí del Chocó en la Costas Atlántica y Pacífica colombianas, respectivamente. Asimismo, en el Yumbalou del Vodú haitiano o en la Santería cubana; en el Candomblé del Brasil o el Spiritual en Estados Unidos. La sabiduría de los Ancestros se transforma en Fe y logra que la religiosidad sea lúcida, histórica y cultural. "La Fe en los poderes mágicos, la certeza de que sus Orishas y Sombras estaban en él -no con él- realiza el milagro de sentirse libre, superior a la muerte, a los amos y a la soledad".

La reiteración del modelo mítico de los rituales funerarios ligados al culto de los Ancestros es primordial para exteriorizar los sentimientos, las frustraciones, el miedo y la esperanza de la liberación, así sea en la otra vida, por lo que el negro adapta las ceremonias de los antepasados a las de los amos, con el objeto de africanizar la sociedad católica, cerrada a cualquier infiltración pagana. Es el caso del Lumbalú o Yambalú, una mezcla de lloro similar al dolido canto de las plañideras, con el baile en torno al cadáver y el retumbar de los tambores para invocar a Elegba, el mensajero de Odumare que conduce a los difuntos Bazimu hacia los Ancestros. La sacralidad de los tambores, la danza y los lloros, a pesar del rechazo de los evangelizadores, se manifiesta además de los rituales funerarios, en las fiestas religiosas y en los convites de desahogo tolerados por los opresores.

El culto a los Ancestros también influye en el destino del negro que respaldado por el vitalismo y el existencialismo de las milenarias religiones africanas, supera la cruda realidad con la reestructura de sus concepciones místicas. Comprometido con los Ancestros a preservar y dignificar la vida, crea sus propios mecanismos de defensa, lo cual implica pelear por ella sin importar el padecimiento físico; obsesionarse con la huida para conservarla, precepto vital más que un anhelo de libertad. "Es evidente que ambos sentimientos debieron estar implícitos en las fugas y resistencia de las comunidades cimarronas" $"$. Esto hace superior al negro ante la adversidad, ante cualquier tipo de ignominia y explotación infrahumana, puesto que dejarse morir es la peor injuria para sus

\footnotetext{
${ }^{65}$ Zapata Olivella, Manuel. Changó, el Gran Putas. Editorial Oveja Negra. Biblioteca de Literatura Colombiana, Bogotá, Colombia, 1983. P.99
} 
Sombras. De igual forma, debe luchar por la creación de una familia, lo que explica la constante búsqueda de la mujer, la procreación desbordante de los hijos y el lazo indisoluble que lo une a los Ancestros y los Dioses del Olimpo africano como Changó, cuyo mandato es combatir por la libertad contra cualquier enemigo usurpador de la misma. En consecuencia, los Ancestros aparecen en la diégesis segmentada en cinco partes, desde la primera fase de la novela, en la cual el imaginario de Zapata Olivella plasma el origen arquetípico de la tierra de los Ancestros. Repite el mito de la creación del mundo, esta vez gracias al poderoso Dios Odumare, del que emanan los Orichas, poseedores de las Sombras sin sus cuerpos; y los hombres perecederos atados con un nudo irrompible a los difuntos, inmortales, amos de la vida.

Presentado el entorno mitológico en el que se desenvolverá la trama, el autor pasa a la Trata, el tráfico humano perpetrado por mercaderes denominados Lobas Blancas, y al viaje trasatlántico de las naos (barcos negreros) hacia el continente del exilio. Aquí retoma el culto a los Ancestros, pues ante la barbarie de los esclavistas, a los negros sólo los reconforta la muerte. El fallecimiento debe ser natural o provocado por el opresor, porque el suicidio lo prohíben sus religiones. Entonces sacan a relucir las "aptitudes mágicas" ligadas a los cantos, las danzas, las fórmulas secretas, influjos sobrenaturales, que los protegen y ayudan a sobrevivir a la esclavitud. En las factorías de embarque, en las naos y puertos de desembarque, a los prisioneros fallecidos les cantan invocando a Elegba, el Oricha que entrelaza a los vivos con los difuntos para que abra las puertas del camino hacia el reencuentro con los Ancestros. Lo mismo sucede en tierra firme, bien sea en las minas, las murallas o en las haciendas, los esclavos suspenden los trabajos, aun sin permiso de los amos, para acompañar a sus muertos con cánticos durante el velorio.

En la segunda parte de la narración, los Ancestros siembran el kulonda de la vida, la fuerza espiritual que interviene en la formación biológica del ser humano para dar nacimiento al Muntu Americano, conformado por la mezcla de sangres que origina las tres etnias imperantes en el mundo afroamericano, el mestizo, el mulato y el zambo. Este Muntu es producto del panteísmo de las religiones africanas, donde además de los Ancestros, el hombre está ligado al resto del universo, incluidos los otros hombres y todo cuanto le sirve de la madre naturaleza animal, vegetal y mineral, que atados en un solo nudo integran ese mundo vital, atávico y arcaico. El mandato del Muntu es combatir por la libertad para evitar 
disgustar a los Dioses y los Ancestros. La filosofía omnisciente del Muntu, sabiduría y conocimiento de todas las cosas reales y posibles, permite sobreponerse a las iniquidades de los esclavistas. Por otro lado, el relato se extiende a la ignominia de la Inquisición que califica al Muntu "hijos de Dios y de la Diabla"66, aumentando el sufrimiento con las persecuciones implacables, las torturas y fusilamientos que diezmaron a muchos de los africanos. El Ancestro protagonista es el personaje fabulado Pupo Moncholo, un Babalao, sacerdote africano, encarcelado en las mazmorras del Santo Oficio:

"Mi estirpe es más vieja que la vuestra. Cuando los Hebreos y Romanos vinieron a disputarse la Tierra Santa mis antepasados ya la habían recorrido [...] Yo puedo contarle por mil noches y mil días las grandes epopeyas de mi pueblo, desde sus orígenes hasta su exilio a este continente por maldición de Changó" ${ }^{\circ 7}$.

El relato continúa con el brote de la rebelión de los Ancestros afroamericanos, de los cuales, el más popular es Domingo Biojó, el Rey Benkos, quien una vez fusilado, se transforma en el Ancestro mártir que evocan los cimarrones palenqueros en Cartagena de Indias. "Eres el escogido por Changó para iniciar la rebelión del Muntu. Tu grito resonará en otras voces, en otras vidas, donde quiera que la Loba Blanca pise la sombra de un negro",68.

En la tercera parte, el escritor se remite entre la ficción y la verosimilitud histórica, a la gesta libertadora de Haití, pionera de las luchas emancipadoras en América. El Vodú es la religión africana que nace en este país, donde el esclavo una vez fallecido, espera que sus dioses le devuelvan la vida en la muerte, para consagrarse eternamente a la venganza y a libertar a sus descendientes y hermanos vivos. El fin único es la libertad. Los Ancestros principales son Ogún Ngafúa y Ogún Olugbala, también creados por la fantasía Zapatiana, que se encargan de avivar los diálogos de los Bazimus, todavía difuntos con energía, cuya próxima transfiguración será en la dimensión de los Ancestros.

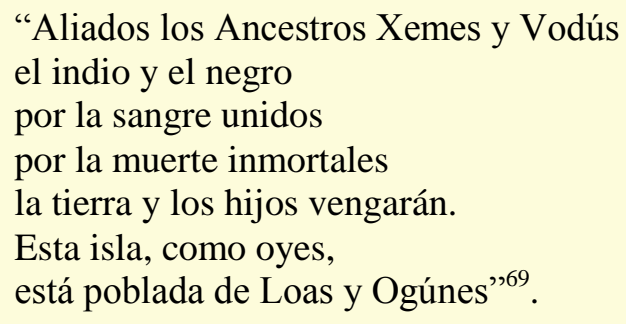

${ }^{66}$ Ibíd. p. 113

${ }^{67}$ Ibíd. p. 147

${ }^{68}$ Ibíd. p. 159

${ }^{69}$ Ibíd. p. 187

Poligramas 35, primer semestre 2011, ISSN 0120-4130. 
Los Bazimus son el emperador colonialista francés Napoleón; el mensajero de Elegba Toussaint-Louverture que abre las puertas a la libertad en la isla; el primer rey negro Henri Christophe; el cimarrón sacerdote Vodú Jean François Mackandal, cuya brujería forja la pasión libertaria entre los esclavos que fundan la primera República americana; y el jamaiquino Bouckman, sucesor de Mackandal.

La cuarta parte trae a la memoria a los Ancestros libertadores de diferentes sangres de Sur y Centroamérica, el mestizo-criollo venezolano Simón Bolívar, el mulato colombiano José Prudencio Padilla, el zambo mexicano José María Morelos y el escultor mestizo brasileño, El Aleijandinho (El Lisiadito). Con estos líderes, el novelista acompañado de los Orichas, recorre los pasos no solo de sus campañas militares, sino de los aciertos y los errores que incluso después de muertos, los historiadores han evitado mencionar para no deteriorar su imagen mitificada.

En la quinta parte de la novela, Zapata Olivella finaliza rindiendo culto a los Ancestros luchadores en Norteamérica, por la reivindicación de los derechos de los negros que se suponen libertos desde la guerra de Secesión en el siglo XIX, pero que en una nación de mayoría xenofóbica, conformada por inmigrantes divididos por el color de la piel y la religión; comandada por grupos exterminadores tan fuertes como el Ku-Klux Clan, se resiste aún en el siglo XX, a aceptarlos y tratarlos como seres humanos libres. Es el cierre del recorrido histórico, donde ideólogos Afroamericanos como Malcom X, Martin Luther King, quienes a pesar de ser asesinados, despiertan de sus moradas en el más allá e implantan el reconocimiento del sentimiento negro, orgulloso de sus divinidades y Ancestros, primeros pobladores del mundo.

En conclusión, la creatividad de Zapata Olivella resuelve en esta maravillosa novela, el paradigma histórico del blanco frente al negro excluido de la sociedad americana por la intolerancia racista, religiosa y clasista. Para este efecto, su imaginario influenciado por la sabiduría del culto a los Ancestros partícipes de la vida cotidiana y a favor de los Orichas directamente ligados a las necesidades inmediatas de los creyentes y más cercanos que el Dios católico. Aún hoy se conserva este culto en comunidades americanas con fuerte ascendencia africana, cuyas mitologías salvadoras han servido para consolar al esclavo, al exiliado, al huérfano, al desprotegido. De esta forma surgen las religiones africanas de 
América: Vodú, Candomblé, Santería, Rastafari, Macumba, Myalismo, Spirituals, Alabados y Lumbalú, entre otras.

\section{Bibliografía}

Eliade, Mircea. El Mito del eterno retorno. Arquetipos y repetición. Emecé Editores, Argentina, 2001.

Zapata Olivella, Manuel. Changó, el Gran Putas. Editorial Oveja Negra. Biblioteca de Literatura Colombiana, Bogotá, Colombia, 1983.

El Árbol Brujo de la Libertad. África en Colombia - orígenes Transculturación - Presencia - Ensayo Histórico Mítico y Antropológico. Artes Gráficas del Valle Ltda. 2002.

Las Claves Mágicas de América. Plaza \& Janés. Editores

Colombia Ltda. 1989. Páginas 96-109. 